\title{
Pertumbuhan Tunas Pisang Barangan Akibat Pemberian Benzyl Amino Purin dan Arang Aktif secara In Vitro
}

\section{Accretion of Barangan Banana Shoot Effect of (BAP) and Activated Charcoal Explant by In Vitro}

\author{
Mulia Saputri ${ }^{1}$, Marai Rahmawati ${ }^{1}$, Elly Kesumawati ${ }^{* 1}$ \\ ${ }^{1}$ Mahasiswa Program Studi Agroteknologi, Fakultas Pertanian, Universitas Syiah Kuala \\ ${ }^{*}$ Staf Dosen Program Studi Agroteknologi, Fakultas Pertanian, Universitas Syiah Kuala
}

\begin{abstract}
Abstrak. Pisang sebagai produk unggulan tanaman hortikultura, belum mencapai produktivitas tinggi dan memiliki beberapa kendala dalam perbanyakannya. Kultur jaringan merupakan salah satu solusi untuk mengatasi masalah tersebut. Penelitian ini bertujuan untuk menentukan komposisi ZPT Benzil Amino Purin (BAP) dan arang aktif yang tepat dalam perbanyakan tunas pisang barangan. Penelitian ini dilakukan di Laboratorium Kultur Jaringan Fakultas Pertanian universitas Syiah Kuala, Darussalam Banda Aceh. Rancangan yang digunakan adalah Rancangan Acak Lengkap (RAL) dengan dua faktor perlakuan. Faktor pertama yaitu konsentrasi BAP terdiri dari 3 taraf yaitu 4 $\mathrm{mg} / \mathrm{L}, 6 \mathrm{mg} / \mathrm{L}$, dan $8 \mathrm{mg} / \mathrm{L}$. Faktor kedua yaitu konsetrasi arang aktif terdiri dari 3 taraf yaitu kontrol, $1 \mathrm{~g} / \mathrm{L}$ dan $2 \mathrm{~g} / \mathrm{L}$. Pada penelitian ini dari 9 kombinasi perlakuan hanya 4 kombinasi perlakuan yang tidak terkontaminasi. Dari 4 kombinasi perlakuan tersebut kombinasi konsetrasi BAP $6 \mathrm{mg} / \mathrm{L}$ dan kontrol (tanpa arang aktif) menunjukkan waktu pertumbuhan tunas yang paling cepat yaitu 29 hari setelah multiplikasi, pertumbuhan tunas yang paling banyak yaitu 6 tunas dan tinggi tunas rata-rata yaitu 15,9 $\mathrm{mm}$.
\end{abstract}

Kata kunci: Pisang barangan, zat pengatur tumbuh, Benzil Amino Purin dan arang aktif.

Abstrak. Banana as a superior product of horticultural crops, has not achieved high productivity and has several obstacles in its multiplication. Tissue culture is one solution to overcome this problem. This study aims to determine the composition of PGRBenzil Amino Purine (BAP) and activated charcoal that are appropriate in the multiplication of barangan banana shoots. This research was conducted at the Tissue Culture Laboratory Faculty of Agriculture Syiah Kuala University, Darussalam Banda Aceh. The design used was a Completely Randomized Design (CRD) with two treatment factors. The first factor is BAP concentration consisting of 3 levels, namely $4 \mathrm{mg} / \mathrm{L}, 6 \mathrm{mg} / \mathrm{L}$, and $8 \mathrm{mg} / \mathrm{L}$. The second factor is activated charcoal concentration consisting of 3 levels, namely control, 1 $\mathrm{g} / \mathrm{L}$ and $2 \mathrm{~g} / \mathrm{L}$. In this study, from 9 treatment combinations, only 4 treatment combinations were not contaminated. Of the 4 treatment combinations the combination of BAP concentration of $6 \mathrm{mg} / \mathrm{L}$ and control (without activated charcoal) showed the fastest shoot growth time of 29 days after multiplication, the most shoot growth was 6 shoots and the average shoot height was $15.9 \mathrm{~mm}$

Keyword : Barangan banana, plant growth regulator, Benzil Amino Purin dan activated charcoal. 


\section{PENDAHULUAN}

\section{Latar Belakang}

Pisang merupakan komoditas pertanian yang bernilai ekonomi tinggi dan merupakan produk unggulan tanaman hortikultura di Indonesia. Buah pisang merupakan salah satu buah yang berpotensi sebagai bisnis usaha dan bahan diversifikasi pangan. Jenis pisang yang banyak diminati salah satunya adalah pisang barangan (Musa acuminata Colla.). Pisang merupakan komoditas penting sehingga ada lembaga dunia yang mengurusi masalah pisang, yaitu International Network for Improvement of Banana and Plantain (INIBAP), yang berkedudukan di Perancis (Ansyori, 2009).

Data Badan Pusat Statistik Pertanian (BPSP, 2017) pada tahun 2015 produksi pisang di Indonesia mencapai 7.299 ton, produksinya menurun pada tahun 2016 menjadi 7.007 ton, hal ini disebabkan tanaman pisang diserang penyakit layu daun (Fusarium oxysporum). Permintaan masyarakat terhadap tanaman pisang terus melonjak karena tingginya konsumsi pisang oleh masyarakat Indonesia (Zebua et al., 2015).

Meningkatnya permintaan pasar terhadap buah pisang barangan ternyata belum diikuti dengan peningkatan produktivitas. Hal ini disebabkan karena petani pisang masih bertani secara tradisional dan mengandalkan pasokkan bibit/anakan yang sangat terbatas, dari 1 tanaman induk pisang barangan, dalam jangka waktu 1 tahun hanya menghasilkan 5 sampai 10 anakan saja (Fiani dan Denian, 1994). Penggunaan bibit yang berasal dari anakan berpeluang besar menularkan penyakit layu fusarium dan layu bakteri, oleh karena itu budidaya pisang dianjurkan menggunakan bibit hasil kultur jaringan. Menurut Balai Penelitian Buah Tropika (Balitbu, 2014) keuntungan bibit dari kultur jaringan yaitu bibit yang dihasilkan mempunyai sifat yang sama dengan induknya, dapat diproduksi secara massal dalam waktu yang relatif singkat dan seragam, tidak butuh lahan yang luas, serta bebas penyakit.

Kultur jaringan tanaman merupakan teknik menumbuhkan dan memperbanyak bagian tanaman baik berupa sel, jaringan atau organ dalam kondisi aseptik secara in vitro pada media bernutrisi lengkap dalam kondisi terkontrol (Yusnita, 2003). Perbanyakan tunas pisang dengan teknik kultur jaringan dapat dilakukan dengan cepat, sehingga dalam waktu satu tahun bisa dihasilkan puluhan sampai ratusan ribu bibit yang berasal dari satu tunas pucuk (George dan Sherrington, 1984).

Zat pengatur tumbuh (ZPT) sangat mempengaruhi keberhasilan kultur jaringan, ZPT digunakan untuk meregenerasikan eksplan sampai menjadi tanaman lengkap. Interaksi antara ZPT yang digunakan pada media kultur akan menentukan arah perkembangan eksplan dari kultur tersebut (Pierik, 1987). Penggunaan ZPT di dalam kultur jaringan tergantung pada tujuan atau arah pertumbuhan tanaman yang diinginkan, jika tujuannya untuk pembentukan tunas umumnya menggunakan ZPT sitokinin. Sitokinin yang paling banyak digunakan pada kultur jaringan adalah kinetin, Benziladenin (BA) atau Benzyl Amino Purin (BAP) (Zulkarnain, 2009).

Aplikasi pemberian sitokinin yang dikombinasikan dengan auksin pada kultur jaringan tanaman pisang telah banyak dilakukan. Penelitian Avivi dan Ikrarwati (2004) menunjukan bahwa pemberian BAP pada konsentrasi $5 \mathrm{mg} / \mathrm{L}$ memberikan hasil terbaik pada parameter jumlah tunas, yaitu 9 tunas per eksplan. Pada penelitian Rendy et al. (2014), konsentrasi BAP yang tepat untuk pembentukan tunas yaitu $2 \mathrm{mg} / \mathrm{L}$, namun pada penelitian Rahmatika (2017) pembentukan tunas terbaik terdapat pada konsetrasi $6 \mathrm{mg} / \mathrm{L}$ BAP.

Pertumbuhan Tunas Pisang Barangan Akibat Pemberian Benzyl Amino Purin dan Arang Aktif secara In Vitro (Mulia Saputri, Marai Rahmawati, Elly Kesumawati) 
Masalah yang sering dihadapi pada kultur pisang adalah terjadinya browning atau pencoklatan pada eksplan. Browning pada kultur jaringan disebabkan karena meningkatnya produksi senyawa fenolat yang diikuti oksidasi oleh aktivitas enzim polifenol oksidase (PPO) dan polimerasinya. Penyebab utama browning dalam kultur jaringan yaitu pada saat jaringan terkena stres mekanik, seperti perlukaan pada waktu proses isolasi eksplan dari tanaman induk atau proses sterilisasi eksplan. Senyawa fenol sering bersifat toksin, menghambat pertumbuhan, bahkan mematikan jaringan eksplan (Hutami, 2008).

Salah satu cara untuk mengatasi dan mengurangi browning yaitu dengan menggunakan arang aktif (Makara et al., 2010). Arang aktif merupakan senyawa karbon amorf yang berfungsi untuk mengurangi terjadinya pencoklatan media akibat pemanasan tinggi selama proses sterilisasi, menyerap senyawa racun dalam media atau menyerap senyawa inhibitor yang disekresikan oleh planlet, menstabilkan $\mathrm{pH}$ media, merangsang pertumbuhan akar dengan mengurangi jumlah cahaya yang masuk ke dalam media dan merangsang morfogenesis (Jamilatun, 2014).

Penambahan arang aktif pada media kultur diperlukan untuk mengurangi browning pada eksplan. Hasil penelitian Kariyana (2013) menunjukkan bahwa penambahan arang aktif dengan konsentrasi optimal $2 \mathrm{~g} / \mathrm{L}$ dapat mengurangi browning pada eksplan, namun pada konsentrasi 0,5 dan $1 \mathrm{~g} / \mathrm{L}$ belum dapat mengurangi efek browning pada pisang Barangan. Berdasarkan permasalahan diatas, untuk mendapatkan bibit pisang Barangan yang dapat diproduksi secara massal dalam waktu singkat dan bebas dari penyakit, maka perlu dilakukan penelitian mengenai perbanyakan pisang secara in vitro dengan berbagai kombinasi konsentrasi BAP dengan arang aktif.

\section{Rumusan Masalah}

1. Apakah konsentrasi BAP mempengaruhi pertumbuhan tunas pisang Barangan secara in vitro?

2. Apakah konsentrasi arang aktif mempengaruhi pertumbuhan tunas pisang Barangan secara in vitro?

3. Apakah terdapat interaksi antara konsentrasi BAP dengan arang aktif terhadap pertumbuhan tunas pisang Barangan secara in vitro?

\section{Tujuan}

Penelitian ini bertujuan untuk mendapatkan kombinasi konsentrasi yang tepat antara BAP dengan arang aktif agar dapat memacu pertumbuhan tunas pisang Barangan.

\section{Hipotesis}

1. Konsentrasi BAP mempengaruhi pertumbuhan tunas pisang Barangan secara in vitro.

2. Konsentrasi arang aktif mempengaruhi pertumbuhan tunas pisang Barangan secara in vitro.

3. Terdapat interaksi antara kombinasi konsentrasi BAP dengan arang aktif terhadap pertumbuhan tunas pisang Barangan secara in vitro. 


\section{METODE PELAKSANAAN}

\section{Tempat dan Waktu}

Penelitian ini dilakukan di Laboratorium Kultur Jaringan Tanaman Fakultas Pertanian Universitas Syiah Kuala Darussalam Banda Aceh yang dimulai pada bulan April 2018 hingga bulan Juli 2018.

\section{Alat dan Bahan}

Alat yang digunakan antara lain laminar air flow cabinet (LAFC), autoclave, magnetic stirer, hot plate, botol kultur, beaker glass $500 \mathrm{ml}$ dan $1000 \mathrm{ml}$, gelas ukur, cawan petri, erlenmeyer, hand sprayer, pinset, scalpel, pisau, lampu bunsen, pipet ukur, korek api, microwave, timbangan analitik, $\mathrm{pH}$ meter, shaker, milimeter block, wadah stainless steel dan alat tulis.

Bahan yang digunakan antara lain, bonggol pisang barangan, bayclin $(\mathrm{NaOCl}) 15 \%, 30 \%$ dan 50\%, fungisida (Dithane M-45), bakterisida (Agrept $20 \mathrm{WP}$ ), aquades, larutan Murashige dan Skoog (MS), alkohol 70\% dan 96\%, stok makro dan mikro, laruta vitamin, larutan mio inositol, gula, kertas label, tisu, ZPT BAP, arang aktif, agar, spiritus, plastik anti panas, dan plastik wrap.

\section{Rancangan Percobaan}

Rancangan Acak Kelompok (RAK) pola faktorial 3 x 3 dengan 3 ulangan, sehingga terdapat 9 kombinasi perlakuan dan 27 unit percobaan.Faktor pertama konsentrasi BAP (B) terdiri dari 3 taraf yaitu $4\left(\mathrm{~B}_{1}\right), 6\left(\mathrm{~B}_{2}\right)$, dan $8\left(\mathrm{~B}_{3}\right) \mathrm{mg} / \mathrm{L}$ dan faktor kedua konsentrasi arang aktif (A) terdiri dari 3 taraf yaitu kontrol $\left(\mathrm{A}_{0}\right), 1\left(\mathrm{~A}_{1}\right)$, dan 2( $\left.\mathrm{A}_{2}\right) \mathrm{g} / \mathrm{L}$. Kombinasi perlakuan konsentrasi BAP dan arang aktif terhadap pertumbuhan tunas pisang barangan dapat dilihat pada Tabel 1.

Tabel 1. Kombinasi konsetrasi BAP dan arang aktif pada pisang barangan

\begin{tabular}{ccc}
\hline Kombinasi & \multicolumn{2}{c}{ Konsentrasi } \\
\cline { 2 - 3 } Perlakuan & BAP $(\mathbf{m g} / \mathbf{L})$ & Arang Aktif $(\mathbf{g} / \mathbf{L})$ \\
\hline $\mathrm{B}_{1} \mathrm{~A}_{0}$ & 4 & kontrol \\
$\mathrm{B}_{1} \mathrm{~A}_{1}$ & 4 & 1 \\
$\mathrm{~B}_{1} \mathrm{~A}_{2}$ & 4 & 2 \\
$\mathrm{~B}_{2} \mathrm{~A}_{0}$ & 6 & kontrol \\
$\mathrm{B}_{2} \mathrm{~A}_{1}$ & 6 & 1 \\
$\mathrm{~B}_{2} \mathrm{~A}_{2}$ & 6 & 2 \\
$\mathrm{~B}_{3} \mathrm{~A}_{0}$ & 8 & kontrol \\
$\mathrm{B}_{3} \mathrm{~A}_{1}$ & 8 & 1 \\
$\mathrm{~B}_{3} \mathrm{~A}_{2}$ & 8 & 2 \\
\hline
\end{tabular}

\section{Pelaksanaan Penelitian}

\section{Sterilisasi Alat}

1) Sterilisasi Laminar Air Flow Cabinet (LAFC)

Semua bagian dalam LAFC disemprot dengan alkohol 70\% kecuali filter hefa, dibersihkan dengan tisu, disemprot lagi dengan alkohol 70\% dan dibiarkan menguap. Lampu Ultra Violet (UV) dinyalakan selama 30 menit, kemudian lampu UV dimatikan dan blower dihidupkan selama 30 menit. 
2) Sterilisasi alat tanam

Sterilisasi pada alat seperti pinset, cawan petri, botol kultur dan scalpel dilakukan dengan cara merendam alat dalam air yang telah dicampur larutan desinfektan (bayclin), lalu dicuci bersih, dibungkus dengan kertas dan dimasukkan ke dalam plastik anti panas, kemudian disterilkan menggunakan autoclave selama 30 menit dengan suhu $126^{\circ} \mathrm{C}$.

\section{Sterilisasi Bahan}

1. Sterilisasi air

Air dimasukkan ke dalam botol kultur dan ditutup rapat menggunakan plastik anti panas, air kemudian disterilkan dengan autoclave pada suhu $121^{\circ} \mathrm{C}$ dengan tekanan 15 Psi selama 20 menit.

2. Sterilisasi media

Media kombinasi perlakuan dimasukkan ke dalam botol kultur steril sebanyak 20 $\mathrm{ml}$ dan ditutup rapat, kemudian disterilkan dalam autoclave pada suhu $121^{\circ} \mathrm{C}$ dengan tekanan 15 Psi selama 20 menit.

\section{Sterilisasi Bonggol Pisang Percobaan Pertama}

Bonggol dibersihkan dan dipotong hingga berdiameter $3 \mathrm{~cm}$ dan panjang $5 \mathrm{~cm}$ pada air yang mengalir. Eksplan yang sudah bersih dimasukkan ke dalam beaker glass yang berisi air bersih. Selanjutnya eksplan dimasukkan dan direndam dalam larutan bakterisida berupa Agrept sebanyak $2 \mathrm{~g} / \mathrm{L}$ sambil diaduk selama 30 menit menggunakan alat shaker kemudia ditiriskan dan direndam kembali dengan larutan fungisida berupa Dithane M-45 sebanyak $3 \mathrm{~g} / \mathrm{L}$ sambil diaduk selama 30 menit menggunakan alat shaker lalu ditiriskan dan dibilas dengan air steril sebanyak tiga kali.

\section{Sterilisasi Bonggol Pisang Percobaan Kedua}

Sebagian besar eksplan pada sterilisasi percobaan pertama mengalami kontaminasi dan eksplan pisang yang masih steril tidak digunakan lagi karena tidak mencukupi untuk ditanam kedalam botol perlakuan sesuai penelitian. Tahapan sterilisasi bonggol pisang percobaan kedua dilakukan sama dengan sterilisasi bonggol pisang percobaan pertama, namun eksplan diaduk di dalam larutan fungisida dan bakterisida secara manual dengan spatula didalam wadah stainless steel selama 60 menit, lalu ditiriskan dan dibilas dengan air steril sebanyak tiga kali. Perbedaan sterilisasi pada percobaan kedua dilakukan agar eksplan yang digunakan lebih steril.

\section{Pembuatan Media}

1. Pembuatan larutan stok A-F

Komposisi garam larutan stok ditimbang sesuai dengan konsentrasi tiap larutan stok seperti pada Lampiran 1, garam stok yang sudah ditimbang kemudian dicampur dengan aquades sampai $1000 \mathrm{ml}$ diaduk sampai homogen menggunakan magneti stirrer, kemudian masingmasing larutan dimasukkan kedalam botol yang telah diberi label.

2. Media inisiasi

Media inisiasi yang digunakan adalah media Murashige dan Skoog (MS). Pembuatan media sebanyak $1000 \mathrm{ml}$, dilakukan dengan dicampurkannya $500 \mathrm{ml}$ air terlebih dahulu, kemudian ditambahkan $10 \mathrm{ml}$ larutan stok A, B, C, D, E, F, Mio Insitol dan vitamin ke dalam beaker glass. Selanjutnya, ditambahkan $30 \mathrm{~g} / \mathrm{L}$ gula dan 
air dicukupkan sampai volume akhir $1000 \mathrm{ml}$. Larutan diaduk hingga larut lalu dimasukkan ke dalam beaker glass dan dipanaskan menggunakan microwave hingga mendidih. Larutan media diukur derajat keasamannya $(\mathrm{pH})$ menggunakan $\mathrm{pH}$ meter sampai mencapai $\mathrm{pH}$ ideal yaitu 5,6-5,8 (jika $\mathrm{pH}$ kurang dari 5,6 ditambahkan beberapa tetes $\mathrm{KOH} 1 \mathrm{M}$, dan bila $\mathrm{pH}$ lebih tinggi dari 5,8 maka ditambahkan beberapa tetes $\mathrm{HCl} 1 \mathrm{M}$ ). Kemudian larutan media inisiasi dimasukkan ke dalam botol kultur steril dengan volume $20 \mathrm{ml}$ dan ditutup rapat. Selanjutnya media disterilisasi di dalam autoclave pada suhu $121^{\circ} \mathrm{C}$ dengan tekanan 15 Psi selama 20 menit.

3. Media multiplikasi

Aquades sebanyak $500 \mathrm{ml}$ dituangkan ke dalam beaker glass ukuran $1000 \mathrm{ml}$. Setiap larutan stok A, B, C, D, E, F, Mio Insitol dan Vitamin, diukur sebanyak $10 \mathrm{ml}$ dan gula sebanyak $30 \mathrm{~g}$ diaduk hingga homogen, kemudian ditambahkan BAP sesuai perlakuan dan larutan dicukupkan hingga $1000 \mathrm{ml}$ dengan ditambahkan aquades, $\mathrm{pH}$ larutan media diukur hingga mencapai $\mathrm{pH}$ 5,6-5,8.

Setelah $\mathrm{pH}$ sesuai, agar-agar ditambahkan ke dalam setiap beaker glass yang berisi larutan media sesuai dengan penelitian sebanyak $7 \mathrm{~g} / \mathrm{L}$ dan diaduk hingga homogen, kemudian ditambahkan arang aktif sesuai perlakuan, lalu larutan dituangkan ke dalam beaker glass dan dipanaskan menggunakan mikrowave hingga mendidih. Setelah mendidih, larutan dituangkan ke dalam botol kultur sebanyak $20 \mathrm{ml}$ dan ditutup dengan plastik anti panas. Larutan media disterilkan menggunakan autoclave pada suhu $121^{\circ} \mathrm{C}$ selama 20 menit. Kemudian media tersebut disimpan di ruang inkubasi selama 1 minggu untuk melihat kontaminasi pada media, jika media tidak terkontaminasi, maka media tersebut dapat digunakan untuk inisiasi.

\section{Inisiasi Percobaan Pertama}

Eksplan dan alat menanam seperti pinset, cawan petri, botol kultur berisi media dan scalpel disemprot dengan alkohol 96\%, lalu dimasukkan ke dalam LAFC. Peralatan disterilkan menggunakan bunsen dengan cara dipanaskan di atas api. Eksplan yang steril

dimasukkan ke dalam larutan bayclin $30 \%$ selama 3 menit, lalu dipindahkan ke cawan petri yang berisi larutan bayclin 50\% kemudian eksplan dikupas bagian pelepah luarnya sebanyak 2-3 lapisan dan dilakukan secara hati-hati agar terhindarnya luka pada eksplan yang dapat menyebabkan terjadinya browning. Eksplan kemudian dicelupkan pada larutan bayclin $15 \%$ dan dilakukan pencucian ke dalam dua botol air steril. Eksplan dilewatkan di atas api bunsen kemudian dimasukkan ke dalam botol kultur yang berisi media inisiasi lalu ditutup rapat menggunakan plastik anti panas. Selanjutnya diberikan keterangan tanggal penanaman dan jenis tanamannya.

\section{Multiplikasi Percobaan Pertama}

Tahapan multiplikasi menggunakan media kombinasi BAP dan arang aktif. Eksplan yang berumur 2-3 minggu yang telah mengalami pembengkakan dan berubah warna menjadi hijau dibersihkan dari lapisan pelepah yang menutupi titik tumbuh. Kemudian bonggol dibelah secara simetris yang harus mengenai titik tumbuhnya, dibagi menjadi empat bagian. Empat bagian dari eksplan pisang ditanam di dalam 1 botol kultur sesuai perlakuan (BAP dan arang aktif). Eksplan yang telah dipotong dibiarkan hingga terjadi pembengkakan. 


\section{Inisiasi Percobaan Kedua}

Tahapan inisiasi eksplan pisang percobaan kedua sama dengan inisiasi eksplan pisang percobaan pertama, namun pada inisiasi eksplan pisang percobaan kedua alat seperti pinset, cawan petri, botol kultur berisi media dan scalpel disemprot dengan alkohol 96\%, lalu dimasukkan ke dalam LAFC dan disinari UV selama 15 menit kemudian dihidupkan blower. Setelah 15 menit tahapan selanjutnya dilakukan seperti pada inisiasi percobaan pertama.

\section{Multiplikasi Percobaan Kedua}

Tahapan multiplikasi eksplan pisang percobaan kedua sama dengan multiplikasi eksplan pisang percobaan pertama, namun 4 bagian eksplan yang sudah dipotong ditanam didalam 2 botol kultur dengan perlakuan yang sama ( 2 bagian eksplan pisang didalam 1 botol kultur) pada setiap perlakuan.

\section{Subkultur}

Eksplan yang sudah mengalami pembengkakan dihilangkan pelepahnya dan dibersihkan dari sel-sel mati. Kemudian dimasukkan ke dalam botol kultur yang berisi media perlakuan(BAP dengan Arang aktif).

\section{Pemeliharaan}

Botol kultur yang telah ditanami eksplan diletakkan di atas rak kultur. Ruangan kultur harus selalu dibersihkan agar terhindar dari kontaminasi. Suhu diatur $16^{\circ} \mathrm{C}$ agar kondisi eksplan berada pada keadaan optimum. Botol yang berada di rak kultur disemprot alkohol $70 \%$ setiap harinya. Apabila eksplan mengalami kontaminasi maka eksplan yang terkontaminasi langsung dipisahkan dan dibawa keluar dari ruang inkubasi agar terhindar dari terjadinya kontaminasi pada eksplan yang lain.

\section{Parameter yang Diamati}

\section{Presentase Eksplan yang Hidup (\%)}

Pengamatan terhadap eksplan dilakukan satu minggu setelah multiplikasi (MSM). Hal yang diamati adalah kontaminasi dan jaringan eksplan yang tidak mati. Rumus menghitung presentase eksplan yang hidup adalah sebagai berikut:

$$
\% \text { Eksplan Hidup }=\frac{\sum \text { Eksplan Hidup }}{\sum \text { Eksplan yang ditanam setiap perlakuan }} \times 100 \%
$$

\section{Presentase Respon Pertumbuhan Eksplan (\%)}

Pengamatan dilakukan pada 2 MSM dengan menunjukkan terjadinya respon pertumbuhan yang berbeda dari perlakuan yang diberikan. Respon pertumbuhan yang diamati ialah pembentukan tunas pada setiap media perlakuan.

$\%$ Respon pertumbuhan eksplan $=\frac{\sum \text { Eksplan yang respon }}{\sum \text { Eksplan yang ditanam setiap perlakuan }} \times 100 \%$

\section{Jumlah Tunas}

Jumlah tunas dihitung dari banyaknya tunas yang tumbuh pada setiap eksplan. Jumlah tunas dihitung setiap minggu sejak mulai tumbuh tunas sampai 9 MSM. 


\section{Tinggi Tunas}

Tinggi tunas diukur menggunakan kertas milimeter block dengan cara menempelkan kertas sejajar dengan media pada botol kultur yang berisi eksplan tersebut dimana posisi kertas sejajar dengan titik tumbuh tunas hingga titik akhir tunas. Pengukuran titik tunas sejak minggu ke-1 sampai 9 MSM (9 kali pengamatan).

\section{Waktu Tumbuh Tunas}

Pengamatan ini bersifat kuantitatif yang dilakukan pada saat muncul tunas pertama. Pengamatan dilakukan sejak minggu ke-1 sampai 9 MSM (9 kali pengamatan).

\section{Warna Tunas}

Pengamatan warna eksplan dilakukan pada saat munculnya tunas dilihat dengan mengamati secara visual. Penentuan warna tunas ditetapkan berdasarkan skoring:
$0:$ Putih (p)
2 : Hijau (h)
1 : Putih Kehijauan (pkh)
$3:$ Merah (m)

\section{HASIL DAN PEMBAHASAN}

\section{Kondisi Laboratorium Kultur Jaringan}

Pada ruang Laboratorium Kultur Jaringan terdapat 3 ruang yaitu ruang persiapan, ruang transfer dan ruang inkubasi. Ruang persiapan digunakan untuk mempersiapkan media kultur dan bahan tanam. Ruang transfer merupakan ruang yang digunakan untuk penanaman eksplan ke dalam media maka dari itu ruangan ini harus steril. Ruang inkubasi merupakan ruang penyimpanan untuk planlet dan eksplan yang baru ditanam, ruangan ini harus selalu bersih dan steril.

Setiap ruangan pada laboratorium kultur jaringan yang ideal yaitu bebas dari kontaminasi, namun kondisi laboratorium kultur jaringan saat penelitian sangat kurang steril. Cat pada dinding di ruang transfer mengalami pengelupasan dan terdapat jamur. Plafon pada ruangan transfer terdapat kebocoran, sehingga menyebabkan munculnya jamur. Keramik pada lantai ruang transfer mengalami kerusakan. Kondisi tersebut sangat mempengaruhi hasil dari penelitian yang dilakukan.

\section{Sterilisasi Percobaan Pertama}

Karena tingginya tingkat kontaminasi di dalam ruang transfer menyebabkan banyak eksplan mengalami kontaminasi, oleh sebab itu dilakukan kembali sterilisasi pada percobaan kedua. Untuk mengurangi kontaminasi maka dilakukan peningkatan sterilisasi pada alat tanam maupun pada eksplan penelitian. Pada percobaan pertama UV pada Laminar Air Flow Cabinet (LAFC) dihidupkan 1 jam sebelum digunakan, alat tanam seperti pinset, cawan petri, botol kultur dan scalpel disterilkan dengan autoclave 1 hari sebelum digunakan selama 30 menit, plastik anti panas yang digunakan untuk sterilisasi alat tanam digunakan sebanyak 3 kali pemakaian, pembersihan laboratorium kultur jaringan dan penyemprotan formalin di dalam ruang inkubasi dilakukan satu bulan sekali.

Pada percobaan pertama bonggol pisang barangan yang digunakan sebanyak 104 bonggol yang berasal dari Balai Benih Hortikultura Saree. Eksplan yang akan digunakan direndam dan diaduk di dalam larutan bakterisida dan fungisida selama 30 menit di dalam beaker glass dengan menggunakan shaker. 


\section{Sterilisasi Percobaan Kedua}

Peningkatan sterilisasi yang dilakukan pada penelitian kedua yaitu, pada percobaan kedua UV pada Laminar Air Flow Cabinet (LAFC) dihidupkan 1 hari sebelum digunakan, alat tanam seperti pinset, cawan petri, botol kultur dan scalpel disterilkan dengan autoclave 2 jam sebelum digunakan selama 30 menit dan disterilkan kembali didalam LAFC dengan disinari UV selama 15 menit sebelum digunakan, plastik anti panas yang digunakan untuk sterilisasi alat tanam digunakan hanya 1 kali pemakaian, pembersihan laboratorium kultur jaringan dan penyemprotan formalin di dalam ruang inkubasi dilakukan satu minggu sekali.

Pada percobaan kedua bonggol pisang barangan yang digunakan sebanyak 27 bonggol yang berasal dari desa Lampasi Engking Aceh Besar. Eksplan pisang yang akan digunakan direndam dan diaduk di dalam larutan bakterisida dan fungisida selama 60 menit secara manual dengan menggunakan spatula di dalam wadah aluminium.

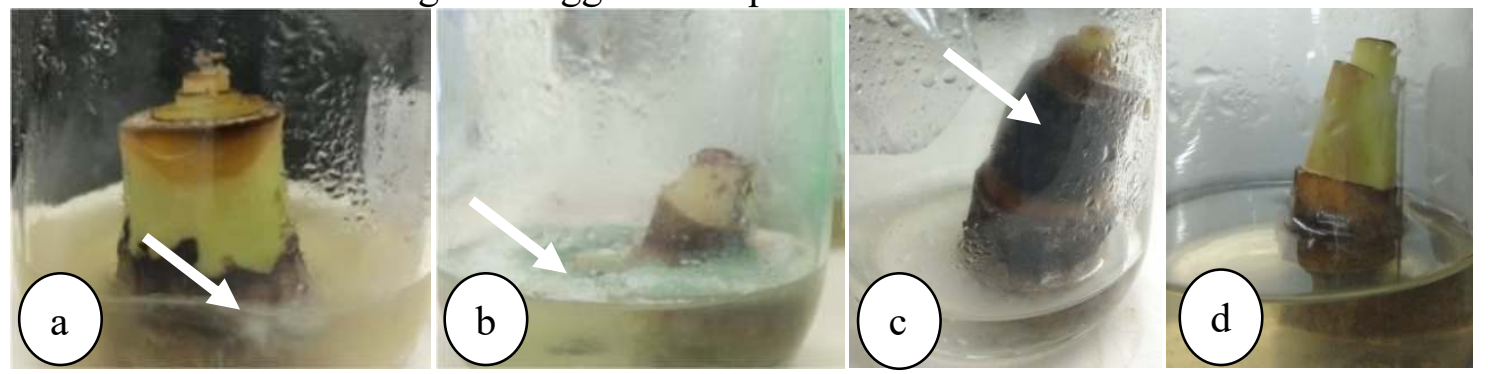

Gambar 1. Eksplan yang terkontaminasi bakteri (a), eksplan yang terkontaminasi jamur (b), eksplan browning (c), eksplan steril (d).

Peningkatan sterilisasi pada alat dan eksplan belum mampu menurunkan tingkat kontaminasi. Pengamatan dilakukan pada eksplan yang masih hidup selama 9 minggu setelah multiplikasi (MSM). Eksplan tunas pisang sebagian besar mengalami kontaminasi sejak 2 MSM. Eksplan yang terkontaminasi bakteri terlihat adanya lendir berwarna putih pada media (Gambar 1.a), eksplan yang terkontaminasi jamur terlihat adanya spora berwarna hijau dan putih yang terdapat pada eksplan dan media (Gambar 1.b), eksplan yang mengalami browning terlihat eksplan berubah warna dari hijau menjadi kecokelatan kemudian layu dan mati (Gambar 1.c), eksplan yang steril terlihat segar dan berwarna hijau (Gambar 1.d).

\section{Inisiasi dan Multiplikasi Percobaan Pertama}

Pada tahap inisiasi percobaan pertama bonggol pisang barangan yang digunakan sebanyak 104 bonggol (Gambar 2.a), yang berasal dari Balai Benih Hortikultura Saree. Sterilisasi yang dilakukan ada dua tahap yaitu inisiasi luar pada ruang persiapan dan inisiasi dalam pada ruang transfer didalam LAFC. Inisiasi luar, bonggol dibersihkan pada air yang mengalir dan dipotong hingga berdiameter $3 \mathrm{~cm}$ dan panjang $5 \mathrm{~cm}$ (Gambar 2.b). Eksplan direndam dalam larutan bakterisida sebanyak $2 \mathrm{~g} / \mathrm{L}$ dan fungisida sebanyak $3 \mathrm{~g} / \mathrm{L}$, kemudian diaduk menggunakan shaker selama 30 menit pada setiap larutan dan ditiriskan (Gambar 2.c). Eksplan dicuci menggunakan akuades steril sebanyak 3 kali dan ditiriskan. Pada inisiasi percobaan pertama terdapat 13 eksplan yang terkontaminasi jamur dan 91 eksplan yang steril, sehingga eksplan pisang pada inisiasi dan multiplikasi percobaan pertama tidak digunakan. 


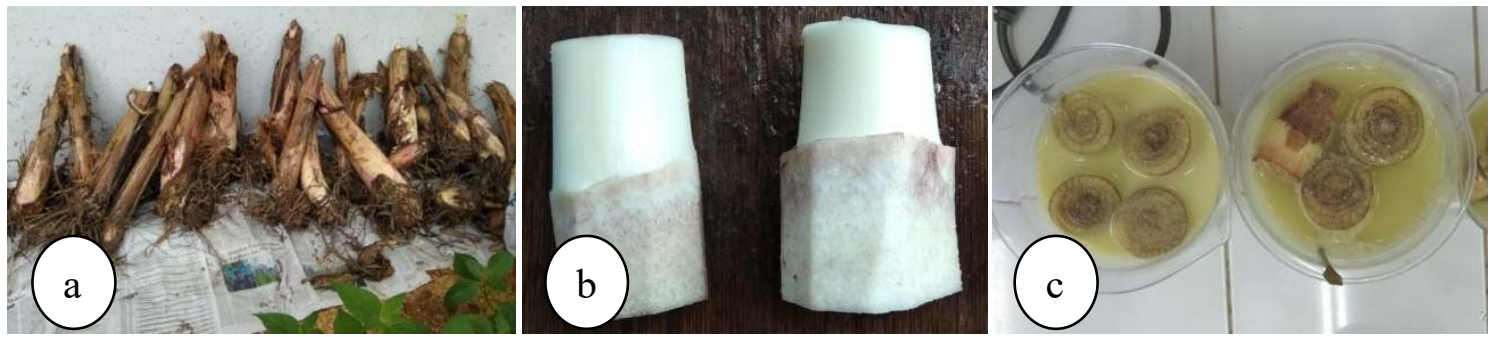

Gambar 2. Bonggol pisang sebanyak 104 bonggol (a), ukuran eksplan pisang untuk inisiasi (b), eksplan yang direndam dalam larutan bakterisida dan fungisida (c).

Untuk memperbanyak tunas pisang secara kultur jaringan dengan menggunakan bonggol pisang, dilakukan pada tahap multiplikasi. Pada tahap ini bonggol pisang dibelah menjadi empat bagian kemudian ditanam di dalam media perlakuan. Pada multiplikasi percobaan pertama untuk satu unit perlakuan dilakukan 9 kali ulangan, satu bonggol pisang dibelah menjadi empat bagian kemudian ditanam kedalam satu botol perlakuan. Setelah 5 hari tahap ini dilakukan, eksplan pisang yang terkontaminasi bakteri sebanyak 59 botol, tekontaminasi jamur sebanyak 11 botol, browning sebanyak 7 botol dan 27 botol yang steril.

\section{Inisiasi dan Multiplikasi Percobaan Kedua}

Inisiasi dan multiplikasi percobaan kedua dilakukan karena terjadi kegagalan pada inisiasi dan multiplikasi percobaan pertama. Pada inisiasi percobaan kedua bonggol pisang barangan yang digunakan sebanyak 27 bonggol yang berasal dari desa Lampasi Engking Aceh Besar. Pada inisiasi 2 ini tidak ada satupun eksplan yang terserang kontaminasi.

Pada multiplikasi percobaan kedua untuk satu unit perlakuan dilakukan 3 kali ulangan, satu bonggol pisang dibelah menjadi empat bagian kemudian ditanam kedalam dua botol perlakuan yang sama (1 botol terdapat 2 bagian eksplan). Setelah 5 hari tahap ini dilakukan, eksplan pisang yang terkontaminasi bakteri sebanyak 10 botol (Gambar 3.a), tekontaminasi jamur sebanyak 7 botol (Gambar 3.b), browning sebanyak 5 botol (Gambar 3.c) dan 32 botol yang bertahan hidup.

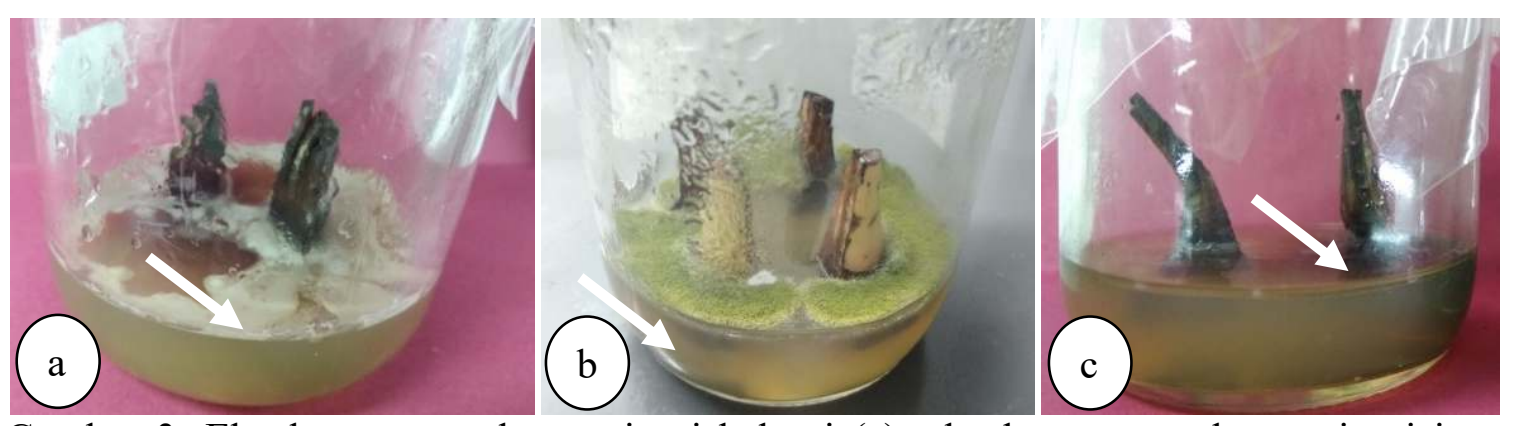

Gambar 3. Eksplan yang terkontaminasi bakteri (a), eksplan yang terkontaminasi jamur (b), eksplan browning (c).

Kontaminasi yang disebabkan oleh bakteri, pada eksplan terlihat lendir berwarna kuning keputihan sebagian lagi melekat pada media membentuk gumpalan yang basah. Sedangkan kontaminasi yang disebabkan oleh jamur terlihat jelas pada media. Media dan eksplan diselimuti oleh spora berbentuk kapas atau miselium yang berwarna putih, hijau dan hitam. Cendawan yang mengkontaminasi media dan eksplan adalah cendawan yang

Pertumbuhan Tunas Pisang Barangan Akibat Pemberian Benzyl Amino Purin dan Arang Aktif secara In Vitro (Mulia Saputri, Marai Rahmawati, Elly Kesumawati)

Jurnal Ilmiah Mahasiswa Pertanian, Vol. 4, No. 1, Februari 2019: 73-90 
biasa ada di laboratorium seperti Monilia Sp, Aspergillus Sp dan Penicillium Sp. Sedangkan bakteri yang muncul dan berasal dari laboratorium adalah bakteri gram positif (Setiyoko, 1995).

Kontaminasi yang disebabkan oleh adanya proses browning (pencoklatan) pada eksplan dalam penelitian ini diduga karena jumlah senyawa arang aktif yang digunakan belum cukup untuk mengabsorbsi asam fenolik yang terdapat pada eksplan. Menurut Hutami (2008), upaya yang dilakukan dalam mengatasi browning yaitu dengan memindahkan eksplan pada media baru, penambahan antioksidan, polivinilpirolidon (PVP) dan asam askorbat (vitamin $\mathrm{C}$ ), namun cara tersebut belum tentu efektif, selain cara-cara tersebut cara yang paling umum digunakan yaitu dengan penambahan arang aktif pada media tersebut. Terjadinya kontaminasi menunjukkan bahwa semakin diperkayanya suatu media dengan nutrisi maka tingkat kontaminasinya juga semakin tinggi. Demikian pula sebaliknya, semakin sederhana komponen media maka akan semakin rendah kemungkinan terjadinya kontaminasi (Santoso dan Nursandi, 2001). Munculnya kontaminan jamur dan bakteri diduga disebabkan oleh rendahnya tingkat sterilisasi ruangan, sumber eksplan yang tidak baik dan prosedur sterilisasi yang dilakukan oleh peneliti belum optimal untuk mensterilkan eksplan dari kontaminan bakteri dan jamur yang berasal dari eksplan.

\section{Subkultur}

Subkultur dilakukan pada saat eksplan pisang telah mengalami pembengkakan. Pelepah pisang dibersihkan dari eksplan, hal ini dilakukan agar tunas pisang lebih mudah untuk tumbuh dari sela-sela pelepah (Gambar 4.b). Eksplan yang sudah bersih dipindahkan pada media baru dengan kombinasi perlakuan yang sama. Pada tahap subkultur eksplan pisang yang steril sebanyak 8 botol (Gambar 4.a), yang terkontaminasi bakteri sebanyak 6 botol (Gambar 4.c) dan tekontaminasi jamur sebanyak 8 botol (Gambar 4.d).
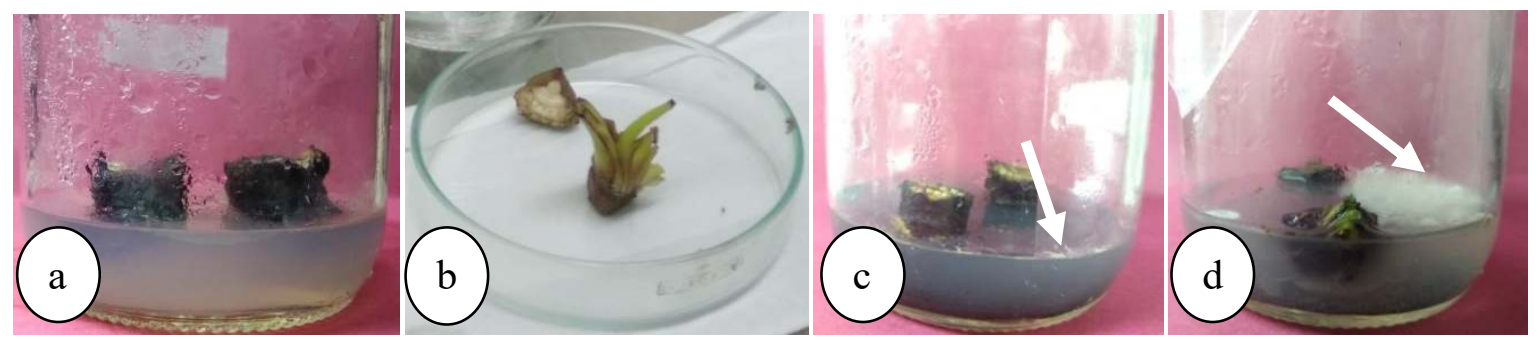

Gambar 4. Eksplan yang steril (a), pembersihan pelepah pisang (b), eksplan yang terkontaminasi bakteri (c), eksplan terkontaminasi jamur (d).

\section{Parameter Pengamatan}

\section{Presentase Eksplan yang Hidup (\%)}

Presentase eksplan yang hidup (\%) pada kombinasi konsentrasi BAP dan arang aktif terhadap jumlah tunas pisang barangan dapat dilihat pada Tabel 2. Pada inisiasi dan multiplikasi percobaan pertama dengan menggunakan media MS. Pengamatan terhadap eksplan dilakukan sejak minggu ke-1 sampai 9 minggu setelah multiplikasi (MSM). 
Tabel 2. Persentase eksplan yang hidup (\%) pada multiplikasi percobaan pertama selama 9 MSM

\begin{tabular}{|c|c|c|c|c|c|c|c|c|c|c|}
\hline \multirow{2}{*}{$\begin{array}{l}\text { Kombinasi } \\
\text { Perlakuan }\end{array}$} & \multicolumn{9}{|c|}{ Persentase eksplan hidup (minggu) } & \multirow{2}{*}{$\begin{array}{c}\text { Total } \\
(\%)\end{array}$} \\
\hline & 1 & 2 & 3 & 4 & 5 & 6 & 7 & 8 & 9 & \\
\hline $\mathrm{B}_{1} \mathrm{~A}_{0}$ & 100 & 88,8 & 88,8 & 88,8 & 88,8 & 0 & 0 & 0 & 0 & 0 \\
\hline $\mathrm{B}_{1} \mathrm{~A}_{1}$ & 100 & 77 & 55 & 0 & 0 & 0 & 0 & 0 & 0 & 0 \\
\hline $\mathrm{B}_{1} \mathrm{~A}_{2}$ & 100 & 55 & 55 & 55 & 0 & 0 & 0 & 0 & 0 & 0 \\
\hline $\mathrm{B}_{2} \mathrm{~A}_{0}$ & 100 & 100 & 100 & 88,8 & 88,8 & 11,1 & 11,1 & 11,1 & 11,1 & 11,1 \\
\hline $\mathrm{B}_{2} \mathrm{~A}_{1}$ & 100 & 66,6 & 55,5 & 0 & 0 & 0 & 0 & 0 & 0 & 0 \\
\hline $\mathrm{B}_{2} \mathrm{~A}_{2}$ & 100 & 55,5 & 55,5 & 0 & 0 & 0 & 0 & 0 & 0 & 0 \\
\hline $\mathrm{B}_{3} \mathrm{~A}_{0}$ & 100 & 100 & 88,8 & 88,8 & 88,8 & 11,1 & 11,1 & 11,1 & 11,1 & 11,1 \\
\hline $\mathrm{B}_{3} \mathrm{~A}_{1}$ & 100 & 100 & 88,8 & 77,7 & 77,7 & 11,1 & 11,1 & 11,1 & 0 & 0 \\
\hline $\mathrm{B}_{3} \mathrm{~A}_{2}$ & 100 & 88,8 & 55,5 & 11,1 & 11,1 & 11,1 & 11,1 & 11,1 & 11,1 & 11,1 \\
\hline Rerata & & & & & & & & & & 3,7 \\
\hline
\end{tabular}

Keterangan: $\mathrm{B}_{1}=\mathrm{BAP} 4 \mathrm{~g} / \mathrm{L} \quad \mathrm{A}_{0}=$ kontrol

$$
\begin{array}{ll}
\mathrm{B}_{2}=\mathrm{BAP} 6 \mathrm{~g} / \mathrm{L} & \mathrm{A}_{1}=\text { arang aktif } 1 \mathrm{mg} / \mathrm{L} \\
\mathrm{B}_{3}=\mathrm{BAP} 8 \mathrm{~g} / \mathrm{L} & \mathrm{A}_{2}=\text { arang aktif } 2 \mathrm{mg} / \mathrm{L}
\end{array}
$$

Pada multiplikasi percobaan kedua rata-rata persentase pertumbuhan eksplan dari minggu ke-1 sampai dengan 9 MSM yaitu sebesar 14,8\%. Dari 9 kombinasi perlakuan hanya 4 kombinasi perlakuan yang bertahan hidup yaitu BAP $6 \mathrm{mg} / \mathrm{L}$ dan kontrol, BAP 8 $\mathrm{mg} / \mathrm{L}$ dan arang aktif $1 \mathrm{~g} / \mathrm{L}$, BAP $4 \mathrm{mg} / \mathrm{L}$ dan arang aktif $2 \mathrm{mg} / \mathrm{L}$ dan BAP $6 \mathrm{mg} / \mathrm{L}$ dan arang aktif $2 \mathrm{~g} / \mathrm{L}$ dapat dilihat pada Tabel 3.

Tabel 3. Persentase eksplan yang hidup (\%) pada multiplikasi percobaan kedua selama 9

\begin{tabular}{|c|c|c|c|c|c|c|c|c|c|c|}
\hline \multirow{2}{*}{$\begin{array}{l}\text { Kombinasi } \\
\text { Perlakuan }\end{array}$} & \multicolumn{9}{|c|}{ Persentase eksplan hidup (minggu) } & \multirow{2}{*}{$\begin{array}{c}\text { Total } \\
(\%)\end{array}$} \\
\hline & 1 & 2 & 3 & 4 & 5 & 6 & 7 & 8 & 9 & \\
\hline $\mathrm{B}_{1} \mathrm{~A}_{0}$ & 100 & 66,6 & 33,3 & 0 & 0 & 0 & 0 & 0 & 0 & 0 \\
\hline $\mathrm{B}_{1} \mathrm{~A}_{1}$ & 100 & 66,6 & 33,3 & 0 & 0 & 0 & 0 & 0 & 0 & 0 \\
\hline $\mathrm{B}_{1} \mathrm{~A}_{2}$ & 100 & 66,6 & 66,6 & 66,6 & 33,3 & 33,3 & 33,3 & 33,3 & 33,3 & 33,3 \\
\hline $\mathrm{B}_{2} \mathrm{~A}_{0}$ & 100 & 66,6 & 66,6 & 66,6 & 33,3 & 33,3 & 33,3 & 33,3 & 33,3 & 33,3 \\
\hline $\mathrm{B}_{2} \mathrm{~A}_{1}$ & 100 & 66,6 & 33,3 & 0 & 0 & 0 & 0 & 0 & 0 & 0 \\
\hline $\mathrm{B}_{2} \mathrm{~A}_{2}$ & 100 & 66,6 & 66,6 & 66,6 & 33,3 & 33,3 & 33,3 & 33,3 & 33,3 & 33,3 \\
\hline $\mathrm{B}_{3} \mathrm{~A}_{0}$ & 100 & 33,3 & 33,3 & 0 & 0 & 0 & 0 & 0 & 0 & 0 \\
\hline $\mathrm{B}_{3} \mathrm{~A}_{1}$ & 100 & 66,6 & 66,6 & 66,6 & 33,3 & 33,3 & 33,3 & 33,3 & 33,3 & 33,3 \\
\hline $\mathrm{B}_{3} \mathrm{~A}_{2}$ & 100 & 33,3 & 33,3 & 0 & 0 & 0 & 0 & 0 & 0 & 0 \\
\hline Rerata & & & & & & & & & & 14,8 \\
\hline eterangan: & $\begin{array}{l}=\mathrm{BA} \\
=\mathrm{BA} \\
=\mathrm{BA}\end{array}$ & $\begin{array}{l}\mathrm{g} / \mathrm{L} \\
6 \mathrm{~g} / \mathrm{L} \\
8 \mathrm{~g} / \mathrm{L}\end{array}$ & & $\begin{array}{l}\mathrm{A}_{0}=1 \\
\mathrm{~A}_{1}=\mathrm{a} \\
\mathrm{A}_{2}=\mathrm{a}\end{array}$ & $\begin{array}{l}\text { itrol } \\
\text { ng al } \\
\mathrm{ng} \text { al }\end{array}$ & $\begin{array}{l}1 \mathrm{mg} \\
2 \mathrm{mg}\end{array}$ & & & & \\
\hline
\end{tabular}
MSM

Pertumbuhan Tunas Pisang Barangan Akibat Pemberian Benzyl Amino Purin dan Arang Aktif secara In Vitro (Mulia Saputri, Marai Rahmawati, Elly Kesumawati) 


\section{Presentase Respon Pertumbuhan Eksplan (\%)}

Presentasi respon pertumbuhan eksplan (\%) pada kombinasi konsentrasi BAP dan arang aktif yang dilakukan pada pisang barangan menggunakan media MS. Respon pertumbuhan yang diamati ialah pembentukan tunas pada setiap media perlakuan dapat dilihat pada Tabel 4.

Tabel 4. menunjukkan bahwa rata-rata persentase respon pertumbuhan eksplan dari minggu ke-1 sampai dengan 9 MSM yaitu sebesar 14,8 \%. Dari 9 kombinasi perlakuan hanya 4 kombinasi perlakuan yang menunjukan respon pertumbuhan yaitu pada kombinasi konsentrasi BAP $6 \mathrm{mg} / \mathrm{L}$ dan kontrol, BAP $8 \mathrm{mg} / \mathrm{L}$ dan arang aktif $1 \mathrm{~g} / \mathrm{L}$, BAP $4 \mathrm{mg} / \mathrm{L}$ dan arang aktif $2 \mathrm{mg} / \mathrm{L}$, BAP $6 \mathrm{mg} / \mathrm{L}$ dan arang aktif $2 \mathrm{~g} / \mathrm{L}$. Dari 3 eksplan yang ditanam pada setiap kombinasi perlakuan hanya 1 eksplan yang menunjukkan respon pertumbuhan pada setiap kombinasi perlakuan.

Tabel 4. Persentase respon pertumbuhan eksplan (\%) pisang barangan selama 9 MSM

\begin{tabular}{ccc}
\hline $\begin{array}{c}\text { Kombinasi } \\
\text { Perlakuan }\end{array}$ & Persentase respon pertumbuhan eksplan & Total (\%) \\
\hline $\mathrm{B}_{1} \mathrm{~A}_{0}$ & 0 & 0 \\
$\mathrm{~B}_{1} \mathrm{~A}_{1}$ & 0 & 0 \\
$\mathrm{~B}_{1} \mathrm{~A}_{2}$ & 33 & 33 \\
$\mathrm{~B}_{2} \mathrm{~A}_{0}$ & 33 & 33 \\
$\mathrm{~B}_{2} \mathrm{~A}_{1}$ & 0 & 0 \\
$\mathrm{~B}_{2} \mathrm{~A}_{2}$ & 33 & 33 \\
$\mathrm{~B}_{3} \mathrm{~A}_{0}$ & 0 & 0 \\
$\mathrm{~B}_{3} \mathrm{~A}_{1}$ & 33 & 33 \\
$\mathrm{~B}_{3} \mathrm{~A}_{2}$ & 0 & 0 \\
\hline Rerata & & \\
\hline Keterangan: $\mathrm{B}_{1}=$ BAP $4 \mathrm{~g} / \mathrm{L}$ & $\mathrm{A}_{0}=$ kontrol & \\
$\mathrm{B}_{2}=$ BAP $6 \mathrm{~g} / \mathrm{L}$ & $\mathrm{A}_{1}=$ arang aktif $1 \mathrm{mg} / \mathrm{L}$ & \\
$\mathrm{B}_{3}=$ BAP $8 \mathrm{~g} / \mathrm{L}$ & $\mathrm{A}_{2}=$ arang aktif $2 \mathrm{mg} / \mathrm{L}$ &
\end{tabular}

\section{Jumlah Tunas}

Jumlah tunas pada kombinasi konsentrasi BAP dan arang aktif yang dilakukan pada pisang barangan menggunakan media MS, jumlah tunas diamati pada saat tunas pertama kali muncul sampai dengan 9 MSM, dapat dilihat pada Tabel 5.

Tabel 5 menunjukkan bahwa dari 4 kombinasi perlakuan, pertumbuhan jumlah tunas terbanyak dijumpai pada kombinasi perlakuan BAP $6 \mathrm{mg} / \mathrm{L}$ BAP dan kontrol yang memiliki jumlah tunas sebesar 6 tunas. Selanjutnya, diikuti perlakuan $\mathrm{B}_{2} \mathrm{~A}_{2}$ memiliki jumlah tunas 5 dengan media pada kombinasi konsentrasi $6 \mathrm{mg} / \mathrm{L}$ BAP dan $2 \mathrm{~g} / \mathrm{L}$ arang aktif. $\mathrm{B}_{1} \mathrm{~A}_{2}$ dengan jumlah 4 tunas pada kombinasi konsentrasi $4 \mathrm{mg} / \mathrm{L}$ BAP dan $2 \mathrm{~g} / \mathrm{L}$ arang aktif dan perlakuan $\mathrm{B}_{3} \mathrm{~A}_{1}$ dengan jumlah 2 tunas pada kombinasi konsentrasi $8 \mathrm{mg} / \mathrm{L}$ BAP dan $1 \mathrm{~g} / \mathrm{L}$ arang aktif. 
Tabel 5. Kombinasi konsentrasi BAP dan arang aktif terhadap jumlah tunas pisang barangan selama 9 MSM

\begin{tabular}{cccccccccccc}
\hline $\begin{array}{c}\text { Kombinasi } \\
\text { Perlakuan }\end{array}$ & $\mathbf{1}$ & $\mathbf{2}$ & $\mathbf{3}$ & $\mathbf{4}$ & $\mathbf{5}$ & $\mathbf{6}$ & $\mathbf{7}$ & $\mathbf{8}$ & $\mathbf{9}$ & Total \\
\cline { 2 - 8 } & & & 0 & 0 & 0 & 0 & 0 & 0 & 0 & 0 & 0 \\
$\mathrm{~B}_{1} \mathrm{~A}_{0}$ & 0 & 0 & 0 & 0 & 0 & 0 & 0 & 0 & 0 & 0 & 0 \\
$\mathrm{~B}_{1} \mathrm{~A}_{1}$ & 0 & 0 & 0 & 0 & 2 & 4 & 4 & 4 & 4 & 4 \\
$\mathrm{~B}_{1} \mathrm{~A}_{2}$ & 0 & 0 & 0 & 2 & 2 & 3 & 3 & 6 & 6 & 6 \\
$\mathrm{~B}_{2} \mathrm{~A}_{0}$ & 0 & 0 & 0 & 0 & 0 & 0 & 0 & 0 & 0 & 0 \\
$\mathrm{~B}_{2} \mathrm{~A}_{1}$ & 0 & 0 & 0 & 0 & 0 & 0 & 3 & 5 & 5 & 5 \\
$\mathrm{~B}_{2} \mathrm{~A}_{2}$ & 0 & 0 & 0 & 0 & 0 & 0 & 0 & 0 & 0 & 0 \\
$\mathrm{~B}_{3} \mathrm{~A}_{0}$ & 0 & 0 & 0 & 0 & 0 & 2 & 2 & 2 & 2 & 2 \\
$\mathrm{~B}_{3} \mathrm{~A}_{1}$ & 0 & 0 & 0 & 0 & 0 & 0 & 0 & 0 & 0 & 0 \\
$\mathrm{~B}_{3} \mathrm{~A}_{2}$ & 0 & \multicolumn{7}{c}{$\mathrm{A}_{0}=$ kontrol } \\
\hline Rerata & \multicolumn{8}{c}{$\mathrm{A}_{1}=$ arang aktif $1 \mathrm{mg} / \mathrm{L}$} & & & \\
\hline Keterangan: $\mathrm{B}_{1}=\mathrm{BAP} 4 \mathrm{~g} / \mathrm{L}$ & $\mathrm{A}_{2}=$ arang aktif $2 \mathrm{mg} / \mathrm{L}$ & &
\end{tabular}

\section{Tinggi Tunas}

Tinggi tunas pada kombinasi konsentrasi BAP dan arang aktif pada pisang barangan menggunakan media kombinasi perlakuan dapat dilihat pada Tabel 6 .

Tabel 6. Kombinasi konsentrasi BAP dan arang aktif terhadap tinggi tunas pisang barangan selama 9 MSM

\begin{tabular}{|c|c|c|c|c|c|c|c|c|c|c|}
\hline \multirow{3}{*}{$\begin{array}{l}\text { Kombinasi } \\
\text { Perlakuan }\end{array}$} & \multicolumn{9}{|c|}{ Tinggi tunas (mm) } & \multirow{3}{*}{ Total $(\mathbf{m m})$} \\
\hline & \multicolumn{9}{|c|}{ Minggu ke } & \\
\hline & 1 & 2 & 3 & 4 & 5 & 6 & 7 & 8 & 9 & \\
\hline $\mathrm{B}_{1} \mathrm{~A}_{0}$ & 0 & 0 & 0 & 0 & 0 & 0 & 0 & 0 & 0 & 0 \\
\hline $\mathrm{B}_{1} \mathrm{~A}_{1}$ & 0 & 0 & 0 & 0 & 0 & 0 & 0 & 0 & 0 & 0 \\
\hline $\mathrm{B}_{1} \mathrm{~A}_{2}$ & 0 & 0 & 0 & 0 & 0,9 & 3,6 & 4,5 & 4,9 & 5,0 & 5,0 \\
\hline $\mathrm{B}_{2} \mathrm{~A}_{0}$ & 0 & 0 & 0 & 0,7 & 2,3 & 3,6 & 6,6 & 14,9 & 15,9 & 15,9 \\
\hline $\mathrm{B}_{2} \mathrm{~A}_{1}$ & 0 & 0 & 0 & 0 & 0 & 0 & 0 & 0 & 0 & 0 \\
\hline $\mathrm{B}_{2} \mathrm{~A}_{2}$ & 0 & 0 & 0 & 0 & 0 & 0,9 & 1,7 & 3,1 & 3,8 & 3,8 \\
\hline $\mathrm{B}_{3} \mathrm{~A}_{0}$ & 0 & 0 & 0 & 0 & 0 & 0 & 0 & 0 & 0 & 0 \\
\hline $\mathrm{B}_{3} \mathrm{~A}_{1}$ & 0 & 0 & 0 & 0 & 0 & 0 & 0,1 & 0,4 & 0,4 & 0,4 \\
\hline $\mathrm{B}_{3} \mathrm{~A}_{2}$ & 0 & 0 & 0 & 0 & 0 & 0 & 0 & 0 & 0 & 0 \\
\hline Rerata & & & & & & & & & & 2,7 \\
\hline
\end{tabular}

\begin{tabular}{rlr}
\hline Keterangan: $\mathrm{B}_{1}=\mathrm{BAP} 4 \mathrm{~g} / \mathrm{L}$ & $\mathrm{A}_{0}=$ kontrol \\
$\mathrm{B}_{2}=\mathrm{BAP} 6 \mathrm{~g} / \mathrm{L}$ & $\mathrm{A}_{1}=\operatorname{arang}$ aktif $1 \mathrm{mg} / \mathrm{L}$ \\
$\mathrm{B}_{3}=\mathrm{BAP} 8 \mathrm{~g} / \mathrm{L}$ & $\mathrm{A}_{2}=\operatorname{arang}$ aktif $2 \mathrm{mg} / \mathrm{L}$
\end{tabular}

Tabel 6. menunjukkan bahwa dari 4 kombinasi perlakuan yang menunjukan respon pertumbuhan tunas tertinggi terdapat pada kombinasi perlakuan $6 \mathrm{mg} / \mathrm{L} \mathrm{BAP}$ dan $0 \mathrm{~g} / \mathrm{L}$ arang aktif $\left(\mathrm{B}_{2} \mathrm{~A}_{0}\right)$, yang memiliki tinggi tunas rata-rata sebesar 15,9 milimeter (Gambar 5.a). Perlakuan $B_{1} A_{2}$ memiliki tinggi tunas rata-rata 5,0 milimeter dengan media pada

Pertumbuhan Tunas Pisang Barangan Akibat Pemberian Benzyl Amino Purin dan Arang Aktif secara In Vitro (Mulia Saputri, Marai Rahmawati, Elly Kesumawati) 
kombinasi konsentrasi $4 \mathrm{mg} / \mathrm{L}$ BAP dan $2 \mathrm{~g} / \mathrm{L}$ arang aktif (Gambar 5.b). Selanjutnya, diikuti perlakuan $\mathrm{B}_{2} \mathrm{~A}_{2}$ dengan tinggi tunas rata-rata $3,8 \mathrm{~mm}$ pada kombinasi konsentrasi 8 $\mathrm{mg} / \mathrm{L}$ BAP dan $1 \mathrm{~g} / \mathrm{L}$ arang aktif (Gambar 5.c) dan perlakuan B3A1 dengan tinggi tunas rata-rata 0,4 milimeter pada kombinasi konsentrasi $6 \mathrm{mg} / \mathrm{L}$ BAP dan $2 \mathrm{~g} / \mathrm{L}$ arang aktif (Gambar 5.d).

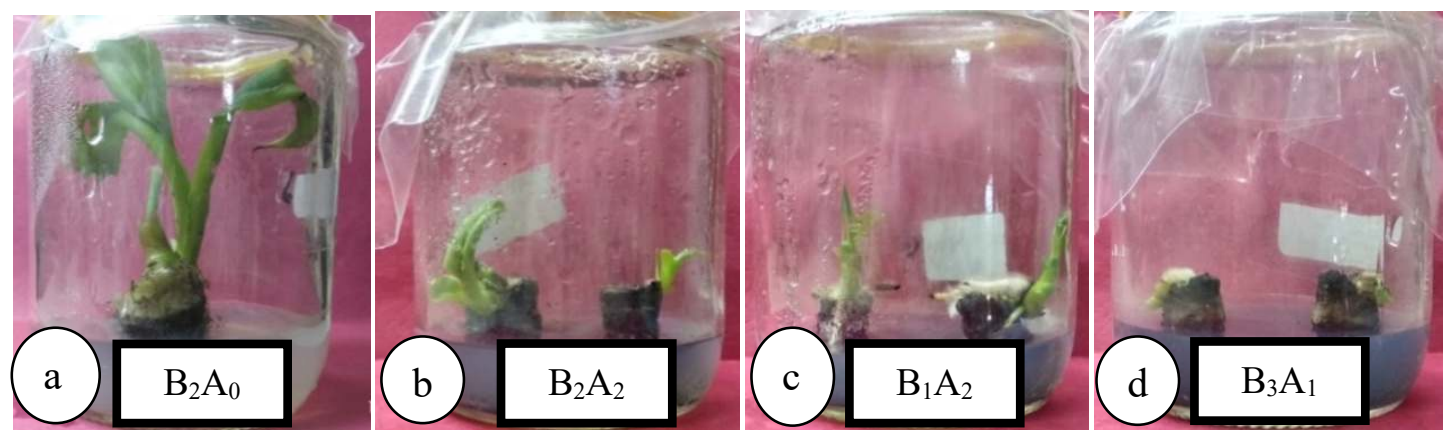

Gambar 5. Eksplan pada kombinasi konsentrasi (a) BAP $6 \mathrm{mg} / \mathrm{L}$ dan kontrol, BAP $6 \mathrm{mg} / \mathrm{L}$ dan arang aktif $2 \mathrm{~g} / \mathrm{L}$ pada $9 \mathrm{MSM}$ (b), BAP $4 \mathrm{mg} / \mathrm{L}$ dan arang aktif $2 \mathrm{~g} / \mathrm{L}$ (c), BAP $8 \mathrm{mg} / \mathrm{L}$ dan arang aktif $1 \mathrm{~g} / \mathrm{L}(\mathrm{d})$.

\section{Waktu Muncul Tunas}

Waktu muncul tunas pada kombinasi konsentrasi BAP dan arang aktif pada pisang barangan mennggunakan media MS dapat dilihat pada Tabel 7.

Tabel 7. Kombinasi konsentrasi BAP dan arang aktif terhadap waktu muncul tunas pisang barangan

\begin{tabular}{ccc}
\hline $\begin{array}{c}\text { Kombinasi } \\
\text { Perlakuan }\end{array}$ & $\begin{array}{c}\text { Waktu Muncul Tunas } \\
\text { HSM }\end{array}$ & Keterangan \\
\hline $\mathrm{B}_{1} \mathrm{~A}_{0}$ & - & Tidak hidup \\
$\mathrm{B}_{1} \mathrm{~A}_{1}$ & - & Tidak hidup \\
$\mathrm{B}_{1} \mathrm{~A}_{2}$ & 45 & Hidup \\
$\mathrm{B}_{2} \mathrm{~A}_{0}$ & 29 & Hidup \\
$\mathrm{B}_{2} \mathrm{~A}_{1}$ & - & Tidak hidup \\
$\mathrm{B}_{2} \mathrm{~A}_{2}$ & 52 & Hidup \\
$\mathrm{B}_{3} \mathrm{~A}_{0}$ & - & Tidak hidup \\
$\mathrm{B}_{3} \mathrm{~A}_{1}$ & 44 & Hidup \\
$\mathrm{B}_{3} \mathrm{~A}_{2}$ & - & Tidak hidup \\
\hline Keterangan: $\mathrm{B}_{1}=$ BAP $4 \mathrm{~g} / \mathrm{L}$ & $\mathrm{A}_{0}=$ kontrol & \\
$\mathrm{B}_{2}=$ BAP $6 \mathrm{~g} / \mathrm{L}$ & $\mathrm{A}_{1}=$ arang aktif $1 \mathrm{mg} / \mathrm{L}$ & \\
$\mathrm{B}_{3}=$ BAP $8 \mathrm{~g} / \mathrm{L}$ & $\mathrm{A}_{2}=$ arang aktif $2 \mathrm{mg} / \mathrm{L}$ & \\
HSM = hari setelah multiplikasi &
\end{tabular}

Tabel 7. Menunjukkan dari 9 kombinasi perlakuan pada penelitian ini hanya 4 kombinasi perlakuan yang tidak terkontaminasi yaitu BAP $6 \mathrm{mg} / \mathrm{L}$ dan kontrol, BAP 8 $\mathrm{mg} / \mathrm{L}$ dan arang aktif $1 \mathrm{~g} / \mathrm{L}$, BAP $4 \mathrm{mg} / \mathrm{L}$ dan arang aktif $2 \mathrm{mg} / \mathrm{L}$, BAP $6 \mathrm{mg} / \mathrm{L}$ dan arang aktif $2 \mathrm{~g} / \mathrm{L}$. menunjukkan bahwa kombinasi konsentrasi BAP $6 \mathrm{mg} / \mathrm{L}$ dan kontrol (B2A0) merupakan waktu tercepat dalam pembentukan tunas. Waktu muncul tunas pada perlakuan 
konsentrasi BAP 6 mg/L dan arang aktif kontrol (B2A0) pada hari ke-29 MSM. Perlakuan kombinasi B2A0 menunjukkan waktu tumbuh tunas yang lebih cepat dibandingkan dengan penelitian Rahmatika (2017) yang menggunakan kombinasi BAP $6 \mathrm{mg} / \mathrm{L}$ dan NAA 0,5 $\mathrm{mg} / \mathrm{L}$. Hal ini diduga karena penggunaan sitokinin (BAP) yang optimal yaitu $6 \mathrm{mg} / \mathrm{L}$ dan penggunaan auksin yang rendah. Hal ini sesuai dengan pernyataan Sitohang (2005), bahwa apabila penambahan auksin lebih rendah dibandingkan sitokinin maka akan terbentuk tunas. Perlakuan BAP $8 \mathrm{mg} / \mathrm{L}$ dan arang aktif $1 \mathrm{~g} / \mathrm{L}$ (B3A1) menunjukkan pertumbuhan tunas pada hari ke-44. Perlakuan BAP $4 \mathrm{mg} / \mathrm{L}$ dan arang aktif $2 \mathrm{~g} / \mathrm{L}$ (B1 A2) menunjukkan pertumbuhan tunas pada hari ke-45. Waktu pertumbuhan tunas terlama terdapat pada perlakuan BAP $6 \mathrm{mg} / \mathrm{L}$ dan arang aktif $2 \mathrm{~g} / \mathrm{L}$ (B2A2) menunjukkan pertumbuhan tunas pada hari ke-52.

\section{Warna Tunas}

Warna tunas yang terlihat pada eksplan pada saat pertama kali muncul tunas yaitu bewarna putih kehijauan (0) (Gambar 6.a) dan berupah menjadi hijau (2) pada 2 minggu setelah tunas muncul (Gambar 6.b).
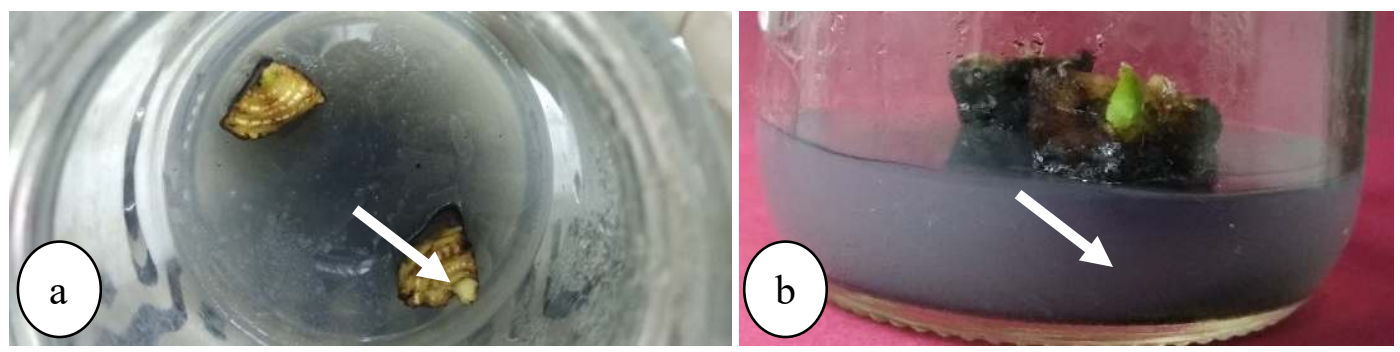

Gambar 6. Tunas pertama muncul (a), Dua minggu setelah tunas muncul (b).

\section{SIMPULAN DAN SARAN}

\section{Kesimpulan}

1. Kombinasi konsentrasi BAP $6 \mathrm{mg} / \mathrm{L}$ dan kontrol menunjukkan waktu pertumbuhan tunas pisang barangan yang paling cepat yaitu 29 hari setelah multiplikasi dan pertumbuhan tunas yang paling banyak yaitu 6 tunas dan tinggi $15,9 \mathrm{~mm}$.

2. Eksplan yang menunjukkan pertumbuhan tunas pisang barangan terdapat pada kombinasi konsetrasi BAP $6 \mathrm{mg} / \mathrm{L}$ dan kontrol, BAP $8 \mathrm{mg} / \mathrm{L}$ dan arang aktif $1 \mathrm{~g} / \mathrm{L}$, BAP $4 \mathrm{mg} / \mathrm{L}$ dan arang aktif $2 \mathrm{~g} / \mathrm{L}$, BAP $6 \mathrm{mg} / \mathrm{L}$ dan arang aktif $2 \mathrm{~g} / \mathrm{L}$.

\section{Saran}

1. Kultur jaringan membutuhkan kondisi yang steril terlebih pada ruangan yang digunakan, untuk mengurangi tingkat kontaminasi ruangan yang rusak harus segera diperbaiki.

2. Perlu adanya penelitian mengenai sterilisasi eksplan yang lebih efektif untuk mengatasi kontaminasi. 


\section{DAFTAR PUSTAKA}

Avivi, S dan Ikrarwati. 2004. Mikroprooagasi Pisang Abaca (Musa textillis) melalui Teknik Kultur Jaringan. Jurnal Ilmu Pertanian. 11(2) : 27-34.

Ansyori. 2009. Kriteria kesesuaian lahan untuk tanaman pisang cavendish yang dikelola secara intensif di Way Kambas Lampung Timur. Disertasi. Institut Pertanian Bogor. Bogor.

Badan Pusat Statistika Pertanian (BPSP). 2017. Data Hortikultura : Kementrian Pertanian. Tersedia online di http:www.pertanian.go.id/ap_pages/mod/datahorti. [14 Maret 2018].

Balai Penelitian Tanaman Buah Tropika (Balitbu). 2014. Teknik Perbanyakan Pisang Ambon Secara Kultur Jaringan. Solok. Kementrian Pertanian.

Fiani, A dan A. Denian. 1994. Teknologi Budidaya Pisang. Dalam: Proseding Seminar Penelitian Tanaman Pangan no 05 - 1994 Balai Penelitian dan Pengembangan Tanaman Pertanian Sub Balai Penelitian Tanaman Pangan Solok. Hal 65 - 67.

George, E. F and P.D. Sherrington. 1984.Plant Propagatin by Tissue Culture.Handbook and Directionary of CommersialLaboratories.Exegetic Ltd. England.

Hutami, S. 2008. Masalah Pencoklatan Pada Kultur Jaringan. Jurnal Agrobiogen. 4(2):83-88.

Jamilatun, S dan M. Setyawan. 2014. Pembuatan Arang Aktif dari Tempurung Kelapa dan Aplikasinya untuk Penjernihan Asap Cair. Spektrum Industri. 12(1) : 1-12.

Kariyana, K and Nisyawati. 2013. Effect Of Ascorbic Acid, Activated Carbon and Light duration on Explant Browning of Banana Cultivar Barangan (Musa acuminata L.) in Vitro Culture. IJRRAS. 16(1):121-122.

Makara, A. M, P. R. Rubaihayo and M. J. S Magambo. 2010. Carry-over effect of Thidiazuron on banana in vitro proliferation at different culture cycles and light incubation conditions. African Journal of Biotechnology. 9(21):3079-3085.

Pierik, R.L.M. 1987. In Vitro Culture of Higher Plants. Martinus Nijhoff Publisher. Netherland.

Rahmatika, W. 2017. Penggunaan Zat Pengatur TumbuhBenzil Amino Purin (BAP) dan Naphthalene Acetic Acid (Naa) Terhadap Induksi Tunas Pisang Barangan (Musa acuminata Colla.) secara In Vitro. Skripsi. MIPA, Biologi, Universitas Syiah Kuala Darussalam. Banda Aceh.

Rendy, D. R. D, D. Sufarna and D. M. Rao. 2014. Effects of benzyl amino purine (6BAP) on in vitro shoot multiplication of grand naine (Musa sp). International Journal of Advanced Biotechnology and Research. 5(1):36-42, ISSN 0976-261.

Santoso, U. dan F. Nursandi. 2001. Kultur Jaringan Tanaman. Penerbitan Fakultas Pertanian Universitas Brawijaya, Malang.

Setiyoko, B. 1995. Kultur Meristem Tanaman Pisang (Musa paradisiaca L.) Kultivar Ambon untuk Memperoleh Tanaman yang Bebas Cucumber Mosaic Virus. Laporan Skripsi Fakultas Biologi Univer-sitas Gadjah Mada, Yogyakarta.

Sitohang, N. 2005. Kultur Meristem Pisang Barangan (Musa paridisiaca L.) pada Media MS dengan Beberapa Komposisi Zat Pengatur Tumbuh NAA, BAP, IBA dan Kinetin. Jurnal Ilmu Pertanian. 3(2):19-25.

Yusnita. 2003. Kultur Jaringan Cara Memperbanyak Tanaman Secara Efisien. Agromedia Pustaka. Jakarta.

Pertumbuhan Tunas Pisang Barangan Akibat Pemberian Benzyl Amino Purin dan Arang Aktif secara In Vitro (Mulia Saputri, Marai Rahmawati, Elly Kesumawati) 
Zebua, D., S, Rahayu dan H. Saleha. 2015. Induksi Tunas Pisang Barangan (Musa acuminata L.) Asal Nias Utara Melalui Kultur Jaringan dengan Pemberian 2,4-D dan Kinetin. Jurnal Biosains 1(2):1-5.

Zulkarnain. 2009. Kultur Jaringan Tanaman (Solusi Pebanyakan Tanaman Budidaya). Bumi Aksara. Jakarta. 
